Historia Slavorum Occidentis

2021, nr 1 (28)

ISSN 2084-1213

DOI: $10.15804 /$ hso210104

\author{
Mariusz Bartnicki (Lublin)
}

ORCID 0000-0002-9021-359X

\title{
Ziemie nadbużańskie w pamięci polskich i ruskich kronikarzy XII-XIII w.
}

Słowa kluczowe: pogranicze, Ruś, Polska, rzeka Bug, Rurykowicze, Piastowie, Powieść lat minionych, Kronika halicko-wołyńska

Keywords: borderland, Ruthenia, Poland, Bug river, Rurikids, Piasts, Tale of Bygone Years, Halych-Volynian chronicle

\begin{abstract}
The article deals with the issue of the Polish-Ruthenian part of the Bug river in the Middle Ages and is an attempt to explain how the area was perceived by inhabitants of the two neighboring countries.
\end{abstract}

Ziemie nadbużańskie należą do tych regionów, które od lat fascynują badaczy. Ten zróżnicowany pod względem krajobrazowym obszar, zaliczany zazwyczaj do dwu odmiennych megaregionów: Przedalpejskiej Europy Środkowej (część zachodnia) oraz Niziny Wschodnioeuropejskiej (część wschodnia) od zakończenia drugiej wojny światowej stał się terenem pogranicza Polski i ówczesnego ZSRR, obecnie zaś jest wschodnią rubieżą Unii Europejskiej i NATO. Wyjątkowy charakter ziem międzyrzecza Wieprza i Bugu wynika nie tylko z jego walorów przyrodniczych, (dolina Bugu jest zaliczana do najmniej przekształconych dolin rzecznych w Europie) ${ }^{1}$, lecz także kultu-

1 H. Wójciak, D. Urban, Poleska dolina Bugu, walory przyrodnicze i kulturowe, [w:] Na międzyrzeczu Wisty i Bugu. Krajobrazy roślinne i dziedzictwo kulturowe środkowowschodniej Polski, red. B. Czarnecka, Lublin 2016, s. 143-144. 
rowych. Wielowiekowa rywalizacja o wspomniane terytoria Polski i Rusi Kościołów katolickiego i prawosławnego spowodowała, że region ten jest również zróżnicowany pod względem etniczno-wyznaniowym, a jego współczesny krajobraz znaczą świątynie wszystkich wyznań - kościoły, cerkwie prawosławne i unickie, synagogi².

Pograniczny charakter ziem nadbużańskich powodował, że w historiografii ze wspomnianym terytorium wiązano pewne wyobrażenia dotyczące sfer peryferyjnych: przekonanie o znikomym rozwoju osadnictwa ${ }^{3}$, przestrzeni, która rozdzielała grupy ludzkie o odmiennych systemach wartości i tradycjach kulturowych ${ }^{4}$. Mieszkańcom międzyrzecza Wieprza i Bugu historiografie narodowe przypisywały często określoną narodowość, utożsamiając ją z ludnością wschodniosłowiańską (czyli ruską) bądź zachodniosłowiańską (polską) .

Warto jednak spojrzeć na dzieje tego mikroregionu z nieco innej perspektywy, potraktować ziemie nadbużańskie nie tyle jako pole badań, ile jako przedmiot badań,

2 B. Czarnecka, Od redaktora, [w:] Na międzyrzeczu Wisty i Bugu, s. 7-8.

3 Np. W. Semkowicz utożsamiał granice Polski Bolesława Chrobrego z granicami naturalnymi, które stanowily puszcze, pasma górskie oraz wododziały rzeczne. Wspomniany badacz przypuszczał, że nieliczne osadnictwo pogranicza było ściśle związane z militarnym ubezpieczeniem „naturalnych bram” wiodących w głąb ziem piastowskich. Zob. tenże, Geograficzne podstawy Polski Chrobrego, Kwart. Hist. 39 (1925), z. 2, s. 259-260, 301-305; zob. także F. Persowski, Studia nad pograniczem polsko-ruskim w X-XI w., Wroclaw 1962, s. 7 n.

4 W. Semkowicz, Geograficzne podstawy Polski, s. 259-260.

5 Szczególnie gorącą dyskusję w historiografii budziła kwestia „geografii plemiennej” pogranicza polsko-ruskiego, w trakcie której arbitralnie wiązano wymieniane w źródłach plemiona z ludnością wschodnio- lub zachodniosłowiańską. Zob. H. Łowmiański, Lędzianie, Slavia Antiqua 4 (1953), s. 42; S.M. Kuczyński, Wschodnia granica państwa polskiego w X w. (przed rokiem 980), [w:] Początki państwa polskiego. Księga Tysiąclecia, t. I, Warszawa 1962, s. 237-238, 243; T. Wasilewski, Dulebowie - Lędzianie - Chorwaci. Z zagadnień osadnictwa plemiennego i stosunków politycznych nad Bugiem, Sanem i Wista w X w., Przegl. Hist. 67 (1976), z. 2, s. 181-187; М. Грушевский, Історія України-Руси, t. I, Київ 1991, s. 206-208; А.Н. Насонов, Русская земия и образование территории древнерусского государства, Москва 1951, s. 130-133; G. Labuda, Polska, Czechy i Ruś w kraju Lędzian w drugiej połowie X w., Rocznik Przemyski 24-25 (1986), s. 283-286; Н.Ф. Котияр, О соииальной сущности Аревнерусского государства IX - первой половины $X$ в., [w:] Аревнейшиие государства Восточной Европы. Материалы и исследования. 1992-1993 г., Москва 1995, s. 34-35; А.Б. Головко, Аревняя Русв и Польша в политических взаимоотношениях X - первой трети ХІІІ вв., Киев 1988, s. 8-9. Krytyczne uwagi na temat posługiwania się kryteriami etnicznymi dla wyznaczania granic między władztwem Piastów i Rurykowiczów wygłosił na początku XX stulecia S. Zakrzewski, Nad Wieprzem i Bugiem w wieku XI i XII, Przegl. Hist. 1 (1905), nr 3, s. 359. Por. K. Fokt, Zagadka plemion znad Bugu, Sanu, Dniestru i Styru, Przegl. Hist. 95 (2004), nr 4, s. $441-442$. 
innymi słowy przyjrzeć się, jak wspomniany obszar był definiowany i postrzegany w pamięci społeczeństw obu sąsiadujących krajów. Taki postulat w sytuacji, kiedy dysponujemy ograniczonym zasobem wiadomości źródłowych dotyczących kształtowania się wschodnich rubieży Polski, wydaje się w praktyce trudny, ale nie niemożliwy do zrealizowania. Jak zobaczymy niżej, w narracjach kronikarskich odbijały się niekiedy refleksy poglądów ówczesnych dotyczące confinium władztwa Piastów i Rurykowiczów. Warto podkreślić, że tego rodzaju „detale”, jakkolwiek okazjonalnie pojawiające się w materiale źródłowym, są szczególnie cenne w badaniach nad szeroko ujmowanym pograniczem.

Najczęściej przytaczanym przekazem w kontekście kształtowania się granicy politycznej między władztwem Rurykowiczów a Piastów jest zapiska najstarszej kroniki ruskiej, tzw. Powieści lat minionych. Pod rokiem 981 wspomina ona o wyprawie księcia kijowskiego Włodzimierza I Wielkiego na „Lachów” i zajęciu przez władcę ruskiego Przemyśla, Czerwienia i innych grodów ${ }^{6}$. Wspomnianą nazwą „Lachy" w piśmiennictwie staroruskim określano Polaków, jakkolwiek kwestia, na kogo w rzeczywistości wyprawiał się Włodzimierz, była wielokrotnie dyskutowana przez badaczy. Rzecz w tym, że istnieją poważne wątpliwości, czy pod koniec X w. obszar ów znajdował się granicach monarchii piastowskiej. Geografia polityczna ziem południowo-wschodniej Europy nie przedstawia się w świetle źródel pisanych jednoznacznie, stad też formułowano różne hipotezy dotyczące przeciwników księcia kijowskiego (Lędzianie/Lachowie/Chorwaci/Czesi?)7). Zanim jednak rozważymy wspomnianą kwestię i przyjrzymy się terytorium, jakie zajął Włodzimierz I, celowe wydaje się powrócić do jednego z kluczowych pytań, znajdujących się często na marginesie refleksji nad wspomnianym przekazem - do kwestii jego wiarygodności i okoliczności powstania.

Badacze, analizując zapis o wyprawie Włodzimierza na Przemyśl i Czerwień, ulegali sugestywnej wizji rozwoju piśmiennictwa staroruskiego, jaką na przełomie

6 Маврентьевскал ^етопись, [w:] Полное собрание русских летописей [dalej PSRL], t. I,

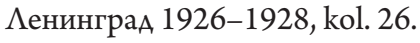

7 Podsumowanie dotychczasowej literatury przedmiotu zob. A. Jusupović, „Червенъ и инь грады" or „гроды Червеньскыл"? History of the domain of Cherven' in the written record ( $9^{\text {th }}-13^{\text {th }} c \mathrm{cc}$ ), [w: ] From Cherven' Towns to Curzon Line: The lands on the Middle Bug during the Middle Ages and the historiographic perspective on the formation of Poland's eastern border, $18^{\text {th }}-21^{\text {st }}$ centuries. Od Grodów Czerwieńskich do linii Curzona. Dzieje środkowego Pobuża w wiekach średnich oraz postrzeganie formowania się wschodniej granicy Polski $w$ historiografii XVIII-XXI w., t. 1: U źródet Europy Środkowo-Wschodniej = Frühzeit Ostmitteleuropas, t. 3, cz. 1, red. M. Wołoszyn, Kraków 2017, s. 61-64. 
XIX i XX w. zbudował Aleksiej Aleksandrowicz Szachmatow ${ }^{8}$. Zakładała ona, że Powieść lat minionych, w wersji która zachowała się do naszych czasów (w redakcji z 1377 r.), jest finalnym rezultatem rozwoju działalności piśmienniczej, jaką na Rusi prowadzono co najmniej od lat trzydziestych XI w. ${ }^{9}$ Informacje o wyprawach Włodzimierza na sąsiednie kraje i ludy traktowano jako wiarygodną i pewną wiadomość, która trafiła do pierwszej redakcji Powieści lat minionych (tzw. Początkowego Zbioru z 1043 r.) z jakiegoś wcześniejszego źródła o charakterze annalistycznym. Dostrzegłszy znaczne trudności z pogodzeniem ze sobą informacji Powieści o wyprawach Włodzimierza, prześcigano się w pomysłach, jak skorygować tekst, doszukując się błędów i niedopowiedzeń późniejszych redaktorów Powieści ${ }^{10}$.

Nie wchodząc w niezwykle rozległą tematykę dotyczącą początku latopisarstwa na Rusi, która wymagałaby odrębnego studium, należy zwrócić uwagę na badania tekstologiczne, które korygują i częściowo obalają tezy A. Szachmatowa, zwłaszcza te dotyczące wczesnych początków piśmiennictwa na Rusi. Analityczne prace An-

8 А.А. Шахматов, Разыскания о древнейших русских летописных сводах, СанктПетербург 1908; tenże, Повесть временных ^ет, ПиотрограА 1916, s. XI; tenże, О Начальном Киевском яетописном своде, [w:] Чтенія въ Императорскомь Обществп Исторіи и Аревностей Россійскихъ при Московскомъ Университетть, Москва 1897, вып 3 , s. 1-58; tenże, Предисловие к Начальному киевскому своду и Несторова летопись, Известия Отделения русскаго языка и словесности Императорской Академии наук 1908, Кн. 1, т. 13; tenże, Киевский Начальный свод 1095 2., [w:] Шахматов (1864-1920). Сборник статей и материалов, поА реА. акаА. С.П. Обнорского, Москва-ИенинграА 1947, s. 117-160.

9 Tenże, Разыскания, $\$ \$ 221-228$; tenże, О Начальном Киевском метописном своде, s. 1-58; tenże, Киевский Начальный свод 1095 г., s. 117-160.

10 S.M. Kuczyński, O wyprawie Wtodzimierza I ku Lachom na podstawie wzmianki z roku 981 w „Opowieści lat doczesnych”, [w:] Studia z dziejów Europy Wschodniej X-XII w., Warszawa 1965, s 82-84; 104. R. Jakimowicz, Szlak wyprawy kijowskiej Bolesława Chrobrego w świetle archeologii, Rocznik Wolyński 3 (1934), s. 82; T. Wasilewski, Dulebowie - Ledzianie - Chorwaci, s. 189; А.В. Назаренко, Аревняя Русь на международных путлх: Междисиипинарные очерки культурных, торговых, политических отночений IX-XII веков, Москва 2001, s. 408; J. Widajewicz, Południowo-wschodnie kresy Polski w Xi XI w., Poznań 1937, s. 3; В.Т. Пашуто, Внешняля политика Аревней Руси, Москва 1968, s. 33; В.А. Королюк, Западные славяне и Киевская Русь в X-XI вв., Москва 1964, s. 89; G. Labuda, Studia, t. 2, Poznań 1988, t. 1, s. 182 n; S.M. Kuczyński, O wyprawie Wtodzimierza, s. 74 n; A. Poppe, Gród Wotyń: z zagadnień osadnictwa wczesnośredniowiecznego na pograniczu polsko-ruskim, [w:] Studia Wczesnośredniowieczne, t. 4, Wrocław-Warszawa 1958, s. 234. Zob. uwagi A. Jusupovića, „Червенъ и ины грады”", s. 67-68; F. Persowski, Studia nad pograniczem, s. 97-101 n. Krytyczne uwagi na temat wiarygodności przekazu podnosiła już E. Kowalczyk, Momenty geograficzne państwa Bolesława Chrobrego. Na styku historii i archeologii, Kwart. Hist. 107 (2000), s. $57 \mathrm{n}$. 
drzeja Poppego wykazują dowodnie, że pierwsza redakcja Powieści mogła powstać najwcześniej w latach siedemdziesiątych XI w., chociaż sam badacz skłonny był ją przesuwać na lata dziewięćdziesiąte XI w. ${ }^{11}$ Dociekania Simona Franklina ${ }^{12}$, Tatiany Vilkul $^{13}$, jak również ostatnie studium Aleksieja Tołoczki ${ }^{14}$ nad tekstem nie pozostawiają złudzeń, że wspomniane dzieło było i jest przede wszystkim wizją historii Rusi spisaną z perspektywy autora końca XI lub przełomu XI i XII w., któremu przyszło odtworzyć ją na podstawie funkcjonujących w jego czasach opowieści, podań, legend oraz nielicznych źródeł pisanych ${ }^{15}$.

Autor Powieści zapewne posiadał wiadomości o starciach militarnych na pograniczu polsko-ruskim, jednakże kwestią dyskusyjną jest, czy w końcu XI lub początku XII stulecia pamiętano jeszcze detale owego pierwszego zderzenia interesów władztwa Rurykowiczów i Piastów. Warto również podkreślić, że postać Włodzimierza I została w Powieści ujęta w konwencji literackiej typowej dla przedstawienia władcy neofity, przeistaczającego się z wojowniczego barbarzyńcy nękającego okoliczne ludy licznymi najazdami w monarchę arcychrześcijańskiego, miłującego pokój i dbającego o bliźnich ${ }^{16}$. Przedstawiając przebieg wyprawy Włodzimierza I na zachód, autor Powieści sądził, że była ona skierowana ku Lachom/Polakom (co z perspektywy XII w. było stwierdzeniem oczywistym, ponieważ Polska była zachodnim sąsiadem

11 А.В. Поппэ, А.А. Шахматов и спорные начала русского летописания, Материаль Международной конференции «Повесть временных лет и начальное летописание» (К 100-летию книги А.А. Шахматова Разыскания о древнейших русских летописных сводах (Москва, 22-25 октября 2008 г.), Аревняя Русь. Вопросы медиевистики 33 (2008), s. 76-85.

12 S. Franklin, Borrowed Time: Perceptions of the Past in Twelfth-Century Rus', [w: ] Perception of the Past in Twelfth Century Europe, ed. by P. Magdalino, London 1992, s. 157-171; tenże, Writing, Society and Culture in Early Rus' c. 950-1300, Cambridge 2004.

13 Т. Виккул, Новгородскал первал летопись $и \ll$ Начальный свод», Paleoslavica 11 (2003), s. 5-35; taż, Толковая Палея и Повесть временных лет. Сюжет о раздплении языюљ, Ruthenica 7 (2007), s. 37-85.

14 А.П. Толочко, Очерки начальной Руси, Киев-Санкт-Петербург 2015.

15 Tamże, s. 49-68. Badacz zakwestionował wiarygodność chronologii Powieści, dowodnie wykazując, że powstała ona w sposób sztuczny, jej kośćcem były zaś daty trzech traktatów ruskobizantyjskich.

16 M. Bartnicki, Władca i poddani w historiografii ruskiej XI-XIII wieku, Lublin 2015, s. 153-184. O znaczeniu Włodzimierza I w wykładzie dziejów Rusi świadczy fakt, że jest to władca, któremu poświęcono w Powieści najwięcej uwagi. Wynikało to z koncepcji utworu, w którym rozłożono akcenty na dokonaniach dwu wielkich przedstawicieli dynastii Rurykowiczów: Włodzimierza I oraz jego godnego naśladowcy Włodzimierza Monomacha, na którego dworze powstały zachowane do naszych czasów wersje Powieści. 
władztwa Rurykowiczów), charakteryzując zaś obszar, który stał się miejscem polsko-rusko rywalizacji, wymienił nazwy dwu grodów - Przemyśla oraz Czerwienia ${ }^{17}$.

Przemyśl chyba nie przypadkowo został w zapisce wymieniony pierwszy ${ }^{18}$. W końcu XI stulecia (1087 r.) wspomniany gród był już centrum udzielnego księstwa Ruryka Rościsławowicza i nie tylko pod względem znaczenia politycznego, ale również gospodarczego (leżał na ważnym szlaku handlowym biegnącym z Regensburga przez Pragę, Kraków na Ruś) deklasował Czerwień ${ }^{19}$.

Drugi z wymienionych grodów od dawna rozpalał wyobraźnię badaczy. Kontrowersje dotyczyły kwestii lokalizacji Czerwienia oraz jego roli w relacjach polsko-ruskich przełomu X i XI w. Zasób źródeł dotyczący wspomnianego ośrodka grodowego jest niezwykle skromny, dlatego też od dawna duże nadzieje wiązano z eksploracją archeologiczną grodziska w Czermnie, uznawanego przez znaczną grupę badaczy za dawny Czerwień ${ }^{20}$. Najnowsze ustalenia archeologów potwierdziły, że gród istniał już w latach osiemdziesiątych $\mathrm{X}$ w., jednakże okres jego świetności i bogactwa przypadał dopiero na wiek XII ${ }^{21}$. Badania paleobotaniczne pozwalają przypuszczać, że poza krótkotrwałym ożywieniem w latach trzydziestych XI w. działalności osadniczej w okolicach Czermna (co wiązać można z wyprawą Jarosława Mądrego z 1031 r. i próbą włączenia obszaru zabużańskiego do ziemi włodzimierskiej) nastąpiła głęboka stagnacja w funkcjonowaniu osady, trwająca do pierwszej

17 Na temat powstawania obecnego brzmienia zapisu zob. T. Wasilewski, Głos w dyskusji, [w:] Pamiętnik X Powszechnego Zjazdu Historyków Polskich w Lublinie, cz. 3, Warszawa 1971, s. 258-259. Badacz uważał, że nazwy grodów zostały wprowadzone do pierwotnej wersji Powieści w latach osiemdziesiątych XI w. Por. uwagi E. Kowalczyk, Momenty geograficzne, s. 60.

18 Zwracali na to uwagę: A.Н. Насонов, Русская земля, s. 132 oraz Н.Ф. Котляр, Формирование территории и возникновение городов Галиико-Вольнской Руси X-XIII вв., Киев 1985, s. 37. 19 Zaliczanie ziemi przemyskiej do tzw. Grodów Czerwieńskich, jeśli takowe w ogóle nie są tworem historiograficznym, wydaje się nie mieć podstaw, zob. A. Poppe, Gród Wotyń, s. 283. Ten dysonans w przekazie Powieści dostrzegał S.M. Kuczyński, O wyprawie Włodzimierza, s. 82-84, 103, dlatego też zaproponował inną emendację zapisu, wedle której Włodzimierz zdobył nie Przemyśl, ale leżący na szlaku wiodącym z Kijowa na Wołyń Peremyl.

20 Zob. M. Wołoszyn, A. Janeczek, R. Dobrowolski, J. Rodzik, P. Mroczek, P. Zagórski, K. Bałaga, I.A. Pidek, I. Hajdas, Beyond boundaries... of medieval principalities, cultures and scientific disciplines: Cherven Towns - insights from archaeology, cartography and paleogeography, [w:] „Castellum, civitas, urbs”. Zentren und Eliten in Fruhmittelaterlichen Ostmitteleuropa. Centres and Elites in Early Medieval East-Central Europe, eds. by O. Heinrich-Tamańska, H. Herold, P. Straub, T. Vida, Castellum Pannonicum Pelsonense, t. 6, Budapest-Leipzig-Keszthely-Rahden 2015, s. 184.

21 Tamże. 
dekady XII stulecia ${ }^{22}$. Zapewne słaba spławność zabagnionego biegu rzeki Huczwy, nad którą posadowiono gród, była jednym z tych czynników, które negatywnie odbiły się na jego rozwoju ekonomicznym. Wspomniana rzeka odgrywała rolę arterii komunikacyjnej jedynie w wymiarze lokalnym ${ }^{23}$. Brak jak dotąd artefaktów (śladów walk, zniszczeń fortyfikacji), które potwierdzałyby jakieś dramatyczne wydarzenia $\mathrm{w}$ dziejach osady związane z rywalizacją polsko-ruską w X-XI w., co pozwala na obecnym etapie badań na sformułowanie hipotezy, że gród ten nie pełnił na pograniczu polsko-ruskim poważniejszych funkcji strategicznych ${ }^{24}$.

Konfrontując obecny stan rozpoznania archeologicznego grodziska w Czermnie z lapidarną zapiską Powieści o wyprawie Włodzimierza na Przemyśl i Czerwień, możemy więc pokusić się o refleksję, że nazwy obu grodów zostały użyte przede wszystkim w kontekście geograficznym. Służyły one określeniu obszaru, który wedle przekonań autora Powieści zajął Rurykowicz w trakcie rywalizacji z zachodnim sąsiadem. Wątpliwości, czy wspomniany fragment Powieści oddaje rzeczywiste wydarzenia, rosną, kiedy przyjrzymy się zapisce przedstawiającej kolejny epizod z dziejów relacji polsko-ruskich, tj. wyprawę władcy polskiego Bolesława Chrobrego na Kijów w 1018 r. Bolesław podjąt interwencję na Rusi w interesie zięcia, księcia ruskiego Świętopełka, który utracił tron kijowski na rzecz brata Jarosława Mądrego. Z przekazu kroniki dowiadujemy się, że wojska polskie bez przeszkód dotarły nad rzekę Bug, gdzie doszło do głównego starcia z wojami ruskimi. Zastanawiające jest, że terytoria Grodów Czerwieńskich, które leżały po zachodniej stronie rzeki, jak podaje ruski kronikarz, władca polański przyłączył do swoich terytoriów w trakcie odwrotu z Kijowa ${ }^{25}$.

Autor Powieści, opisując wydarzenia z przeszłości, wymienił grody, które w jego mniemaniu precyzyjnie określały obszar rywalizacji polsko-ruskiej. Taki sposób porządkowania przestrzeni, przez odwołanie się do grodów - punktów centralnych

22 R. Dobrowolski, J. Rodzik, P. Mroczek, P. Zagórski, K. Bałaga, M. Wołoszyn, T. Dzieńkowski, I. Hajdas, S. Fedorowicz, Environmental conditions of settlement in the vicinity of the mediaeval capital of the Cherven Towns (Czermno site, Hrubieszów Basin, Eastern Poland), Quaternary International 493 (2018), s. 269-271. Tezę o znikomym znaczeniu Czerwienia jako ośrodka administracyjnego i produkcyjnego postawił już A. Poppe, Gród Wołyń, s. 284, przyp. 214.

23 A. Poppe, Gród Wotyń, s. 260-262.

24 Por A. Jusupowić, „Червенъ и ины градъ», s. 73, przyp. 29.

25 Ааврентьевскал летопись, kol. 48-49. „Bolesław zaś uciekł z Kijowa, zabrawszy skarby i bojarów Jarosławowych i siostry jego, a Anastazego z dziesiętynnej cerkwi przystawił do skarbów, bowiem ten pochlebstwami pozyskał jego zaufanie. I ludzi mnóstwo uprowadził ze sobą i Grody Czerwieńskie zajął dla siebie...”, tłum. za F. Sielicki, Powieść minionych lat. Powiest' wriemiennych let, Wrocław 1968, s. 313. 
danego terytorium - był typowy dla historiografii ruskiej. Pytaniem otwartym jest, czy wspomniane w Powieści centra możemy utożsamiać z istniejącymi w czasach spisania kroniki podziałami administracyjnymi władztwa Rurykowiczów na tzw. wołości, czy funkcjonowały one jedynie w umyśle kronikarza i były elementem „kronikarskiego porządkowania świata”26.

Jeśli spojrzymy na dzieje polsko-ruskich kontaktów z perspektywy polskiej tradycji historiograficznej, to okazuje się, że do XV w. i czasów powstania dzieła Annales seu cronicae incliti Regni Poloniae, polskiego kronikarza Jana Długosza ${ }^{27}$, nazwa Czerwień nie pojawiała się w polskich annałach. Wydaje się to zdumiewające, tym bardziej jeśli za tezami części badaczy przyjmiemy, że w X-XI w. gród ów stanowił ważny element systemu obrony zachodnich rubieży władztwa Rurykowiczów. Autor najstarszej polskiej kroniki powstałej w początkach XII w., tzw. Gall Anonim, przedstawiając wyprawy Bolesława Chrobrego na Ruś, odwoływał się tylko do jednego punktu, który przestrzennie określał miejsce konfrontacji polsko-ruskiej - rzeki Bug. Dla Galla była ona wschodnim confinium władztwa Bolesława ${ }^{28}$. W tym właśnie kontekście kronikarz wspominał Bug w epizodzie przedstawiającym powrót Bolesława Chrobrego z Kijowa. Jak pisał Gall: „gdy zaś z ogromną radością i pieniędzmi powracał i już zbliżał się [Bolesław] do granic Polski, zbiegły król, zebrawszy książąt ruskich z Połowcami i Pieczyngami, podążał za nim z tyłu i usiłował pewny zwycięstwa stoczyć walkę nad rzeką Bugiem”29.

Opisując kolejne starcie z Rusinami, kronikarz po raz kolejny wspominał Bug w kontekście rzeki granicznej. „Zdarzyło się mianowicie, że w jednym i tym samym czasie król Bolesław najechał Ruś i król Rusinów Polskę, jeden nie wiedząc o drugim i każdy rozbił obóz u granic ziemi drugiego, przedzielała ich tylko rzeka”30.

26 А. Толочко, Воображенная народность, Ruthenica 36 (2002), s. 112-117.

27 Ioannis Dlugossii, Annales seu cronicae incliti Regni Poloniae, Liber 1-2, Warszawa 1964, s. 269.

28 Galla Kronika, wyd. A. Bielowski, [w: ] MPH, t. 1, Lwów 1864, s. 403.

29 Gall Anonim, Kronika Polska, tłum. R. Grodecki, wstęp, oprac. M. Plezia, Wrocław 1965, s. 24 [podkreślenia tekstu - M.B.] Illum itaque cum ingenti gaudio et pecunia remeantem, iamque Poloniae finibus propinquantem, rex fugitivus collectis virbus ducum Ruthenorum cum Plaucis et Pincinakitis a tergo subsequitur, et ad fluvium Bugam committere certus de victoria conabatur; Galla Kronika, s. 403.

30 Gall Anonim, Kronika Polska, s. 29: contigit namque uno eodemque tempore Bolezlavum regem Rusiam, Ruthenorum vero regem Poloniam, utroque de altero nesciente, hostiliter introisse, eosque super fluvium alterum in alterius termino regionis, interpositio flumine, castra militiae posuisse; Galla Kronika, s. 406. 
Dla piszącego w początkach XII w. Galla nie było więc wątpliwości, że wschodnie rubieże ziem piastowskich w czasach Bolesława sięgały do rzeki Bug i to właśnie tam musiały nastąpić rozstrzygnięcia militarne. Brak wiadomości o Czerwieniu moglibyśmy zrzucić na karb niewiedzy kronikarza, który z perspektywy początku XII stulecia stworzył laudację władcy polskiego Bolesława Chrobrego.

Dysponujemy jednak źródłem pierwszorzędnej wagi, które powstało w czasach, kiedy przedsięwzięto kijowską ekspedycję władcy polańskiego - kroniką Thietmara. Biskup merserburski wiedzę o opisywanych wydarzeniach czerpał zapewne od bezpośrednich uczestników wyprawy kijowskiej z 1018 r. - rycerzy saskich posiłkujących księcia polańskiego ${ }^{31}$. Według Thietmara wojska dowodzone przez Bolesława przybyły 22 VII 1018 r. nad pewną rzekę i tu rozłożyły się obozem, bowiem po drugiej stronie znajdował się obóz króla Rusów. Prowokacje harcowników nieoczekiwanie doprowadziły do starcia zbrojnego. Wojska Bolesława zdołały przeprawić się przez rzekę i rozbić oddziały ruskie. Jak dalej relacjonował kronikarz, po zwycięstwie książę polski ścigał ustępujących nieprzyjaciól, a mieszkańcy kolejnych grodów przyjmowali go $\mathrm{z}$ honorami i darami ${ }^{32}$.

Wersja wydarzeń przedstawiona przez Thietmara jest zgodna z przebiegiem wypadków odnotowanych w Powieści lat minionych. Z relacji źródła ruskiego dowiadujemy się, że władca kijowski Jarosław wyruszył przeciw Świętopełkowi i posiłkującemu go Bolesławowi, kierując swoje wojska ku Wołyniowi ${ }^{33}$. Jak dowodnie wykazał A. Poppe, wzmiankowana w zapisie nazwa Wołyń odnosiła się nie tyle do rozległego terytorium późniejszej ziemi włodzimierskiej, ile do leżącego po lewej stronie Bugu grodu $^{34}$. Badacz apriorycznie zakładał, że Wołyń był grodem ruskim, rzekomo zajętym przez Bolesława, który znacznie szybciej niż jego przeciwnik zmobilizował wojska i ruszył nad Bug ${ }^{35}$. Przeczy temu przekaz Thietmara - uczestnictwo w wyprawie rycerzy saskich oraz współdziałanie księcia polańskiego z Pieczyngami sugerują, że przygotowanie wyprawy również musiało od władcy polskiego wymagać sporo czasu. Wołyń był „wrotami” zarówno do ziemi włodzimierskiej, jak i ziem piastow-

31 Zob. A. Poppe, Spuścizna po Wtodzimierzu Wielkim. Walka o tron kijowski w 1015-1019, Kwart. Hist. 102 (1995), s. 11.

32 Kronika Thietmara, tłum. M.Z. Jedlicki, Kraków 2005, ks. VIII, s. 234-235.

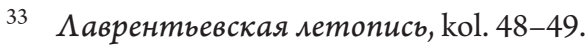

34 A. Poppe, Gród Wotyń, s. 230 n.

35 Tamże, s. 237. 
skich, ważnym punktem obronnym, strzegącym przeprawy przez $\mathrm{Bug}^{36}$. O znaczeniu wspomnianego ośrodka świadczy również dość zagadkowe źródło, tzw. Spis grodów ruskich. Sporządzony najprawdopodobniej w końcu XIV w. tekst zawiera zestawienie ośrodków grodowych nie tylko ruskich, ale również polskich, litewskich, bułgarskich i wołoskich ${ }^{37}$. Wedle ustaleń A. Poppego opierał się on na wcześniejszej redakcji pochodzącej sprzed $1240 \mathrm{r}^{38}$ Powody, dla których sporządzono ów tekst, nie przedstawiają się jasno. Najczęściej wskazywano na jego kompilacyjny charakter lub traktowano jako dzieło, którego celem był opis historyczno-geograficzny ziem ruskich i z nimi sąsiadujących ${ }^{39}$. Dla moich rozważań istotne jest, że w części opisującej grody wołyńskie źródło to wymienia Wołyń, natomiast milczeniem pomija Czerwień ${ }^{40}$. To właśnie nad Bugiem w pobliżu grodu Wołyń rozegrało się rozstrzygające starcie między Piastem a Jarosławem Mądrym.

Warto wspomnieć o jeszcze jednym świadectwie źródłowym, które wielokrotnie było przywoływane przez badaczy w kontekście ustalenia przebiegu południowo-wschodnich rubieży monarchii piastowskiej, tzw. dokumencie praskim. Dokument praski ma niezwykle obszerną literaturę przedmiotu, gdzie możemy znaleźć podsumowanie dotychczasowej dyskusji na temat jego autentyczności oraz wiarygodności zawartych w nim informacji ${ }^{41}$, dlatego uchylę się od ich ponownego referowania i ograniczę się tylko do przedstawienia najważniejszych kwestii istotnych dla przedmiotu rozważań.

Wedle wiadomości przekazanej przez kronikarza czeskiego Kosmasa okoliczności wystawienia dokumentu wiążą się z wydarzeniami, do jakich doszło na synodzie w Moguncji w 1085 r., na którym biskup praski Gebhart wystąpił z supliką dotyczącą połączenia biskupstwa praskiego z morawskim. Uzyskawszy zgodę cesarza oraz akceptację arcybiskupa Wezilona, biskup praski zadbał również o potwierdzenie decyzji u papieża, wysyłając poselstwo na czele z duchownym Albinusem. Ostatecznie postanowienia w sprawie połączenia biskupstwa praskiego i morawskiego zostały umocnione wydaniem przez Henryka IV dokumentu expressis verbis przytoczo-

\footnotetext{
36 Tamże, s. 288-289.

37 Zob. Список русских городов дальних и ближних, реА. М.Н. Тихомиров, Исторические записки 40 (1952), s. 216-220.

38 A. Poppe, Gród Wotyń, s. 256.

39 Список русских городов, s. 219.

40 Tamże, s. 225.

41 Zob. M. Matla-Kozłowska, Pierwsi Przemyślidzi i ich państwo (od X do połowy XI wieku), Poznań 2008, s. 170 n.; D.A. Sikorski, Początki Kościoła w Polsce, Poznań 2012, s. 50 n.
} 
nego przez kronikarza, a zawierającego w treści opis granic dawnego biskupstwa praskiego ${ }^{42}$.

Opowieść Kosmasa od dawna budziła zastrzeżenia historyków. Analiza tej części kroniki wykazała, że jest to amplifikacja kronikarza, który nie miał żadnej wiedzy na temat tego, co tak naprawdę wydarzyło się w Moguncji, stworzył swój przekaz na podstawie tego, co wyczytał z treści dyplomu i dopełnił własnymi domysłami ${ }^{43}$. Warto jednak podkreślić, że poza wersją dokumentu w kronice Kosmasa zachowały się jeszcze dwa przekazy rękopiśmienne: kopia B naśladownicza, datowana na koniec XI w., oraz odpis D. w Liber primus regestrri acclasiae Moguntianae, pochodzący z przełomu XIII i XIV w. ${ }^{44}$ Wedle przypuszczeń Helmuta Beumanna między wspomnianymi trzema przekazami rękopiśmiennymi nie ma filiacji, są one niezależne pod względem treści od siebie, u ich podstawy zaś leżał niezachowany tekst wspólny dla zachowanych rękopisów ${ }^{45}$. Nie wchodząc w dyskusję na temat autentyczności wspomnianego dokumentu, ważne jest to, że oryginał bądź falsyfikat powstał w przedziale lat siedemdziesiątych i osiemdziesiątych XI w. niewątpliwie na użytek biskupstwa praskiego ${ }^{46}$. Dla tematu rozważań szczególnie intrygująca jest ta część dyplomu, w której przytoczono opis granic biskupstwa praskiego:

Granice zaś [jej] diecezji ku zachodowi są takie: Tugust, który rozciąga się aż do środka rzeki Chub, Zedlza i Lusane i Dazana, Liutomerici aż do środkowego lasu, który ogranicza Czechy. Dalej ku północy takie są granice: Pssouane, Chrouati i drugie Chrowati, Zlasane, Trebouane, Pobarane, Dedosize aż do środkowego lasu, gdzie biegną granice Milczan. Stąd ku wschodowi takie ma [diecezja] rzeki graniczne: Bug mianowicie i Ztir, wraz z grodem Gracouua oraz z krajem, który ma nazwę Uuag, oraz ze wszystkimi terytoriami należącymi do wspomnianego grodu, który jest Gracouua ${ }^{47}$.

42 Die Chronik der Böhmen des Cosmas von Prag, hrsg. v. B. Bretholz, MGH SRG, Berlin 1923, Bd. 2, c. 37, s. 134-138; zob. M. Matla-Kozłowska, Pierwsi Przemyślidzi, s. 170; D.A. Sikorski, Początki Kościota, s. 55-56.

43 B. Krzemińska, D. Třeštík, O dokumencie praskim z roku 1086, Studia Źródłoznawcze 5 (1960), s. 91-87; D.A. Sikorski, Początki Kościoła, s. 56.

44 B. Krzemińska, D. Třeštík, O dokumencie, s. 79-87. Wspomniane wersje mogunckie różnią się w detalach od wersji przytoczonej przez Kosmasa.

45 H. Beumann, W. Schlesinger, Urkundenstudien zur deutschen Ostpolitik unter Otto III., Archiv für Diplomatik 1 (1955), Exkurs 1: Das DH IV 390 für Prag von 1086 Apr., s. 236-243. Uwagi na temat koncepcji Beumanna zob. D.A. Sikorski, Początki Kościoła, s. 52-55.

46 D.A. Sikorski, Początki Kościoła, s. 58.

47 Tłumaczenie za G. Labuda, Studia, t. 2, Poznań 1988, s. 130. 
W historiografii zarysowały się zasadniczo dwie przeciwstawne opinie na temat przytoczonego fragmentu. Wedle części badaczy odzwierciedla on zasięg metropolii morawskiej u schyłku X w ${ }^{48}$ bądź oddaje sytuację w okresie powstania biskupstwa praskiego, tj. ok. lat 973-976 ${ }^{49}$. Znacznie liczniejsza grupa historyków sceptycznie podchodzi do informacji zawartych w tej części dokumentu praskiego, uważając, że tzw. opis granic jest fałszerstwem ${ }^{50}$.

Przychylając się do takiego poglądu, warto jednak zastanowić się, jakie przyczyny legły u podstaw takiego wytyczenia granic biskupstwa. Jak zauważył Dariusz A. Sikorski, niewątpliwie opis granic nie służył określonym doraźnym celom biskupstwa praskiego, ponieważ nie odpowiadał ani realiom politycznym końca XI stulecia (wspomniane obszary znajdowały się poza kontrolą czeskiej dynastii Przemyślidów), ani prawnym (na terenach domniemanego obszaru biskupstwa praskiego istniało nie tylko biskupstwo morawskie, lecz także polskie diecezje: krakowska i wrocławska) ${ }^{51}$.

Jeśli nawet opis granic diecezji praskiej był spreparowany przez fałszerza, to musiał on zadbać o to, by jego treść nie budziła podejrzeń. Prawdopodobna wydaje się więc hipoteza, że ta część dokumentu mogła powstać na podstawie jakichś autentycznych dokumentów lub regestrów z czasów początku biskupstwa, w których wyliczano daniny i trybuty z terenów zachodnich i północnych Czech i Śląska ${ }^{52}$. Znacznie trudniejszym zadaniem okazało się wyznaczenie rubieży wschodniej, która została bardzo lakonicznie określona przez podanie nazw dwu rzek o przebiegu południkowym: Bugu i Styru. Możemy snuć jedynie przypuszczenia, że preparując opis, autor falsyfikatu nie budował go całkowicie na fantastycznych założeniach, lecz odwoływał się do funkcjonujących w jego otoczeniu (dworu biskupa praskiego?) pewnych wyobrażeń, dotyczących najdalszego zasięgu dominacji politycznej Przemyślidów. Dla moich rozważań istotne jest, że w końcu XI w. rzeki Bug i Styr

48 K. Potkański, Kraków przed Piastami, Rozprawy AU, Wydz. hist.-filoz. 35 (1898), s. 233; H. Łowmiański, Początki Polski, t. 4, s. 479-493.

49 J. Kalousek, O listine cisaře Jindřicha z roku 1086, kterouž Morava była opět přivitělena k diecesi Pražské, Český časopis historický 8 (1902), s. 257-269; G. Labuda, Studia, t. 1, s. 145-146. Por. M. Matla-Kozłowska, Pierwsi Przemyślidzi, s. 188-219. Wspomniana badaczka uważa dokument praski za autentyczny, a opis granic w nim zawarty za pochodzący z dokumentów fundacyjnych biskupstwa praskiego i morawskiego.

50 A. Lewicki (Wratystaw II czeski królem polskim. Ustęp z dziejów czeskopolskich, Przemyśl 1876, s. 17-22) uważal, że opis granic biskupstwa praskiego oddaje zasięg terytorialny wschodnich rubieży monarchii Bolesława Szczodrego. Zob. D.A. Sikorski, Początki Polski, s. 65-66.

51 Tamże, s. 62.

52 Tamże, s. 69. 
traktowano jako swoistego rodzaju rubież, choć niewątpliwie autor opisu granic biskupstwa praskiego miał dość mgliste pojęcie o biegu obu arterii rzecznych ${ }^{53}$.

Podsumowując tę część rozważań, możemy zauważyć, że w najstarszych przekazach źródłowych powstałych w Polsce i na Rusi w początkach XII w. znajdujemy odmienny sposób definiowania granicy. Autor Powieści lat minionych, opisując obszar, który jego zdaniem stał się zarzewiem konfliktów, odwoływał się do ośrodków grodowych (Czerwienia, Przemyśla) - akcentując przy okazji ich związek z Rusią. Dla ruskiego kronikarza ziemie nadbużańskie, leżące po zachodniej stronie Bugu, należały, poza krótkim epizodem związanym z kijowską wyprawą Bolesława, do domeny Rurykowiczów. Z kolei polski kronikarz wschodnie granice władztwa Piastów utożsamiał $\mathrm{z}$ biegiem rzeki Bug. Wspomniana rzeka funkcjonowała również jako swoista granica w świadomości twórcy dokumentu praskiego. Warto podkreślić, że odwoływanie się do granic naturalnych, wyznaczających obszar, na którym formowała się pierwotna wspólnota społeczna, było typowe dla piśmiennictwa kręgu lacińskiego ${ }^{54}$.

To odmienne pojmowanie rubieży w XII w. w historiografii polskiej i ruskiej nie wynikało chyba tylko z tego, że kronikarze starali się podkreślić zasługi „własnych” dynastów i odwoływali się do znanego nie tylko w czasach nam współczesnych przekonania, że dokąd dotarły wojska danej ze stron, tam sięgała władza satrapy, który je wysła ${ }^{55}$.

Aby lepiej zrozumieć, jak w rzeczywistości wczesnego średniowiecza postrzegano w Polsce i na Rusi obszary pograniczne, odwołamy się do jednego z najważniejszych źródeł do dziejów ziem nadbużańskich - trzynastowiecznej Kroniki halicko-wołyńskiej. Lokalny charakter wspomnianego dzieła, które powstało w leżącym w bezpośrednim sąsiedztwie interesującego mnie obszaru - we Włodzimierzu Wołyńskim lub w Chełmie - czyni zeń nieocenioną skarbnicę wiedzy o pograniczu polsko-ruskim.

Jeden z początkowych fragmentów kroniki opisuje rywalizację o księstwo halicko-włodzimierskie, która wybuchła po nagłej śmierci pod Zawichostem władcy

53 Zwracał na to uwagę W. Kętrzyński, wskazując (Granice Polski w X wieku, Kraków 1892, s. 14), że obie rzeki mają swoje źródła w obwodzie lwowskim (w odległości ok. $35 \mathrm{~km}$ od siebie) i płyną w tym samym kierunku, dlatego też uważał, że w dokumencie praskim jest mowa nie tyle o rzece Styr, ile Seret.

54 J. Tyszkiewicz, Średniowieczne granice wytyczone wzdłuż rzek w Europie Środkowej, [w:] Z dziejów średniowiecznej Europy Środkowo-Wschodniej, Warszawa 2007, cz. 2, s. 145-152.

55 Szerzej o kształtowaniu się mitu granic zob. J. Banaszkiewicz, Fabularyzacja przestrzeni. Średniowieczny przykład granic, [w:] tenże, Takie sobie średniowieczne bajeczki, Kraków 2012, s. 119-147. 
wspomnianych terytoriów - Romana Mścisławowicza. Scheda po zmarłym księciu stała się zarzewiem rywalizacji między książętami ruskimi, jak również przedmiotem zainteresowania sąsiednich władztw: Królestwa Węgier i księstwa krakowsko-sandomierskiego. Jednym z ośrodków grodowych, o które toczyły się walki, był Włodzimierz Wołyński. Rządy przejął tam początkowo książę Światosław Igorewicz, jednakże swoje prawa dziedziczne do głównego grodu ziemi włodzimierskiej zgłosił również inny Rurykowicz, książę bełski Aleksander Wsiewołodowicz ${ }^{56}$. Aleksander zwrócił się o pomoc militarną do książąt polskich: Leszka Białego i Konrada Mazowieckiego. Wojska sojusznicze bez przeszkód sforsowały Bug i dotarly pod Włodzimierz Wołyński. Mieszkańcy postanowili otworzyć bramy grodu. Polacy, którzy pierwsi wkroczyli do Włodzimierza, rzucili się do plądrowania domów, próbując również ograbić cerkiew św. Bogurodzicy. Dopiero przyjazd książąt, którzy postępowali za wojskiem i kary, jakie wymierzono rabusiom, załagodziły sytuację. Autor przekazu, wykorzystując konstrukcję oratio recta, tak skomentował poczynania polskiego rycerstwa: „jeśli nie byłoby z nimi Aleksandra, to nie przeszliby nawet Bugu" 57 .

Pierwsza refleksja, jaka się nasuwa, to pytania, jakim szlakiem poruszały się wojska biorące udział w wyprawie oraz o którym odcinku biegu Bugu wspomina kronikarz. Odpowiedzi nie są proste, ponieważ mimo wielu postulatów szlaki komunikacyjne pogranicza polsko-ruskiego są słabo rozpoznane ${ }^{58}$. Jedynie hipotetycznie zatem można określić miejsce połączenia sił uczestników wyprawy.

Biorąc pod uwagę cel ekspedycji wojskowej - Włodzimierz Wołyński - można przypuszczać, że wojska księcia krakowsko-sandomierskiego Leszka Białego ma-

56 Aleksander Wsiewołodowicz jako bratanek Romana Mścisławowicza posiadał dziedziczne prawa do Włodzimierza Wołyńskiego, zob. D. Dąbrowski, Genealogia Mścisławowiczów. Pierwsze pokolenia (do poczatku XIV wieku), s. 320-327.

57 Kronika halicko-wotyńska (kronika Romanowiczów), [w:] MPH s.n., t. XVI, wyd. D. Dąbrowski, A. Jusupović przy współpracy I. Jurewnej, A. Majorowa, T. Wiłkuł, Kraków-Warszawa 2017, s. 16-18 (dalej cyt. KHW). Tłumaczenie za: KHW, s. 99.

58 Kwestię przebiegu szlaków komunikacyjnych pogranicza polsko-ruskiego najpełniej rozpatrzył A. Poppe, przy okazji rozważań dotyczących grodu Wołyń. Pewnym uzupełnieniem jest również artykuł Z. Szambelana, Najazdy ruskie na ziemię sandomierska $w$ XIII w., Acta Universitatis Lodiensis. Folia Historica 36 (1989), s. 7-32. Warto jednak zauważyć, że charakter podróżowania w średniowieczu, który był swoistym kompromisem między znalezieniem jak najkrótszej drogi, a posuwaniem się wzdłuż charakterystycznych punktów topograficznych (najczęściej dolin rzecznych), ułatwiających orientację w terenie oraz omijających zwarte kompleksy leśne, zmienia nieco ów obraz. Zob. też. F. Persowski, Studia nad pograniczem, s. 7 n. 
szerowały utartym szlakiem komunikacyjnym przez Zawichost, w kierunku Tarnawy, następnie doliną Poru do Sącisk (Sutiejska). Ta ostatnia wymieniona osada musiała pełnić co najmniej od końca XI stulecia funkcję ważnego punktu tranzytowego na drodze z Polski na Ruś. Po raz pierwszy była wzmiankowana jako miejsce ugody zawartej między księciem Włodzimierzem Monomachem a Polakami około 1075 r. ${ }^{59}$ Z Sącisk wojska księcia krakowsko-sandomierskiego mogły ruszyć w kierunku Szczekarzewa, gdzie funkcjonowała przeprawa przez Wieprz (osada Brody), i po sforsowaniu rzeki, doliną Wieprza i Wolicy, dotarły do Grabowca, gdzie krzyżowały się drogi wiodące z Włodzimierza na zachód ze szlakiem biegnącym przez Czerwień w kierunku Bełza. Być może w tej miejscowości doszło do spotkania wojsk Leszka Białego i Aleksandra Bełskiego. Trudno natomiast określić, w którym momencie wyprawy przyłączyły się posiłki mazowieckie. Nie można wykluczyć, że nastąpiło to nad samym Bugiem. Na taką ewentualność wskazują wiadomości Kroniki halicko-wołyńskiej dotyczące pobytu w księstwie mazowieckim Daniela Romanowicza, który szukał schronienia przed najazdem mongolskim pustoszącym Ruś. Kiedy wspomniany książę wyruszył w drogę powrotną na Wołyń, przemieszczał się prawdopodobnie szlakiem wiodącym wzdłuż dolin rzecznych: Wisły, Bugonarwi i Bugu ${ }^{60}$. Wydaje się więc prawdopodobne, że w 1206 r. wojska Leszka Białego, Konrada Mazowieckiego oraz Aleksandra Bełskiego przekroczyły Bug w okolicach grodu Wołyń, dzisiejszego Gródka Nadbużnego.

Uwagę zwraca reakcja autora Kroniki halicko-włodzimierskiej, który podobnie jak Gall rzekę Bug traktowal jako pewnego rodzaju rubież („nie przeszliby nawet Bugu”), i zastanawia, dlaczego za pierwszy gród wołyński, który został zajęty przez wojska polskie, uważał Włodzimierz nie zaś Czerwień leżący na zachodnim brzegu rzeki.

$59 \Lambda$ Аврентьевскал ^етопись, kol. 81 O strategicznej roli Sącisk świadczą również wydarzenia, z 1099 r. w związku z oślepieniem władcy trembowelskiego Wasylka. Jedną z odsłon konfliktu, jaki wówczas wybuchł na Rusi, była rywalizacja o Włodzimierz Wołyński między Dawidem Igorewiczem, sprawcą oślepienia władcy trembowelskiego, a Świętopełkiem kijowskim, występującym w roli obrońcy pokrzywdzonego księcia. Według przekazu Powieści Dawid, który pod Jarosławiem rozgromił wojska władcy kijowskiego i posiłkujących go Węgrów, ruszył w kierunku grodu włodzimierskiego, zajmując po drodze dwa grody: Czerwień i Sąciska. Przypuszczać możemy, że zajęcie tego ostatniego było podyktowane próbą ubezpieczenia się od ewentualnego zagrożenia ze strony Polaków, którzy znajdowali się w gronie sojuszników Świętopełka. Władysław Herman występował w roli mediatora między księciem kijowskim Świętopełkiem a Dawidem. Do mediacji doszło pod Brześciem, jednak zakończyła się ona niepowodzeniem, tamże, kol. 90-91.

60 Por. D. Dąbrowski, Daniel Romanowicz, król Rusi (ok. 1201-1264), Kraków-Warszawa 2013, s. 225. 
Kwestia przynależności tzw. ziemi czerwieńskiej do Wołynia na przełomie XII i XIII stulecia nie przedstawia się jasno. Od połowy XII w. obszar ziemi włodzimierskiej ulegał pogłębiającym się podziałom między potomkami Mścisławowiczów. Według Adriana Jusupovicia prawdopodobnie już w latach osiemdziesiątych XII w. nastąpiło oderwanie ziemi czerwieńskiej od dzielnicy włodzimierskiej, co było pokłosiem rywalizacji księcia Romana Mścisławowicza o tron halicki ${ }^{61}$. Wspomniany książę w czasie pierwszych rządów w Haliczu przekazał władzę nad Włodzimierzem Wołyńskim bratu Wsiewołodowi. Interwencja króla węgierskiego zmusiła wkrótce Mścisławowicza do opuszczenia grodu halickiego. Książę Roman na próżno domagał się od brata zwrotu dzielnicy włodzimierskiej. Zdaniem A. Jusupovicia w wyniku interwencji teścia Ruryka Roman odzyskał władzę we Włodzimierzu, ale Wsiewołod zdołał zatrzymać Czerwień ${ }^{62}$. Argumentem, który potwierdza taki rozwój wydarzeń jest zdaniem wspomnianego badacza to, że gród ów w początkach XIII stulecia należał do potomków księcia ruskiego Wsiewołoda (Aleksandra i jego brata Wsiewołoda). Taka hipoteza tłumaczyłaby więc, dlaczego mieszkańcy Włodzimierza w 1206 r. rzekę Bug uznawali za rubież obronną i wyraźnie odróżniali ją od terenów zabużańskich.

Nie można jednak wykluczyć także innej ewentualności, że przejście Czerwienia pod zarząd Wsiewołodowiczów nastąpiło dopiero w początkach XIII stulecia, właśnie po wspomnianej wyżej wyprawie Leszka Białego, Konrada Mazowieckiego i Aleksandra Bełskiego na Włodzimierz Wołyński. Wedle Kroniki halicko-włodzimierskiej Leszek Biały, który był opiekunem nieletnich synów Romana Mścisławowicza, faktycznie występował w roli dysponenta wołyńskiej części ojcowizny Romanowiczów. Potwierdza to passus Kroniki halicko-wołyńskiej opisującej przybycie na dwór krakowski delegacji mieszkańców Brześcia, którzy prosili księcia Leszka Białego, by rządy w grodzie powierzył wdowie po Romanie oraz jej małoletniemu synowi Wasylowi. Książę miał również wpływ na obsadę tronu włodzimierskiego. Z ipatiewskiej wersji Kroniki halicko-wołyńskiej dowiadujemy się bowiem, że wkrótce po wyprawie wołyńskiej władzę we Włodzimierzu przejął Ingwar, teść księcia krakowskiego, natomiast książę Aleksander powrócił do Bełza. Niezadowolenie bojarów włodzimierskich z rządów Ingwara, jak podaje kronikarz, spowodowało, że Aleksander ponownie objął władzę we Włodzimierzu, pod naciskiem Leszka Białego przekazując Bełz księżnej Romanowej i Wasylowi. Jako swoiste „odszkodowanie” Wsiewołodowicz otrzymał władzę nad grodami nadbużańskimi: Uhruskiem, Wereszczynem, Stołpiem i Kumowem. Wzmiankowany

\footnotetext{
61 A. Jusupović, „Червенъ и инь градь», s. 81.

62 Tamże.
} 
został również Czerwień, nad którym zarząd książę krakowski powierzył bratu Aleksandra - Wsiewołodowi ${ }^{63}$. Książę krakowski, posiadając niekwestionowane wpływy polityczne w sąsiednich księstwach ruskich, realnie decydował więc o obsadzie tronu w Bełzie, Włodzimierzu czy też Brześciu.

Odpowiedź na pytanie, jak postrzegano w początku XIII w. ziemie nadbużańskie, przynosi kolejny fragment kroniki, opisujący wydarzenia, które rozegrały się w latach dwudziestych XIII w. Wówczas to niedawny podopieczny księcia Leszka Białego - Daniel Romanowicz - wyprawił się na „Brześć, Uhrusk, Wereszczyn, Stołpie i Kumów” i „całą okrainę” odebrał swojemu krakowskiemu protektorowi ${ }^{64}$. Obszar ów trafił w bliżej niewyjaśnionych okolicznościach pod zarząd Leszka Białego, zapewne przy okazji kolejnych przetasowań związanych z obsadą tronów w sąsiednich księstwach ruskich. Dla tych rozważań istotne jest, że w świadomości autora Kroniki halicko-wołyńskiej ziemie nadbużańskie, które wedle opinii przeważającej części badaczy od 1031 r. wchodziły w skład włodzimierskiej domeny Rurykowiczów, funkcjonowały w rzeczywistości jako specyficzny obszar, obszar peryferyjny, który odróżniano od dzielnicy włodzimierskiej. Podkreślę raz jeszcze: dla kronikarza piszącego w początku XIII w. ziemia włodzimierska to ziemia rozciągająca się po wschodniej stronie Bugu. Autor, próbując sprecyzować wspomniane peryferia, po raz pierwszy posłużył się określeniem „okraina” czyli skraj, kres, próbując zaś geograficznie określić ów obszar, posłużył się nazwami Brześcia, grodu, który wielokrotnie pojawiał się w przekazach źródłowych w kontekście walk polsko-ruskich, oraz osad: Uhruska, Wereszyna, Stołpia, Kumowa. Powyższy fragment uprawdopodabnia więc tezę, że do początku XIII w. granica polsko-ruska na odcinku nadbużańskim miała charakter tzw. granicy głębokiej. Jakkolwiek obszar ów znalazł się w strefie wpływów Rurykowiczów, pytaniem fundamentalnym jest, na czym polegało to podporządkowanie. Brak wiadomości źródłowych o budowie nowych grodów - symboli władzy książęcej - oraz to, że Czerwień - uważany za gród centralny rozległego obszaru tzw. Grodów Czerwieńskich - faktycznie nie miał większego znaczenia militarnego, może sugerować, że zwierzchność ta była jedynie nominalna ${ }^{65}$. Książęta wołyńscy, zadowalając się symboliczną podległością ziem po lewej stronie Bugu, traktowanych

\footnotetext{
63 KHW, s. 19-21.

64 Tamże, s. 59-60.

65 Próbę ściślejszego związania Czerwienia z ziemią włodzimierską podjął po 1031 r. Jarosław Mądry. Badania paleobotaniczne i archeologiczne pozwalają jednak wysunąć hipotezę, że był to krótkotrwały epizod w dziejach Czerwienia i okolic i wkrótce po 1031 r. jest wyraźnie uchwytna stagnacja gospodarcza wspomnianego obszaru.
} 
jako sfera peryferyjna, nie widzieli konieczności budowy grodów na tym terenie czy też kontroli nad nielicznymi osadami przez wprowadzanie w nich nieustannej obecności załóg. Warto przy tym podnieść, że od lat czterdziestych XI w. w relacjach polsko-ruskich nastąpiła wyraźna i długotrwała zmiana. Ślub księcia polskiego Kazimierza Odnowiciela z księżniczką ruską Dobroniegą-Marią zapoczątkował okres zbliżenia między oboma monarchiami, które umacniały kolejne liczne mariaże. Dzielnicą włodzimierską, pod której zarządem znajdowały się ziemie nadbużańskie, często rozporządzali władcy, w których żyłach płynęła krew Piastów i Rurykowiczów. W czasach, kiedy obszar państwa był traktowany jako prywatna domena monarchy, a o prawach do danego terytorium decydowały często względy spadkowe, nie było to zapewne bez znaczenia.

Wracając do wyprawy Daniela Romanowicza na „ziemie okrainne”, należy odnotować, że spotkała się ona z odwetowymi działaniami ze strony Leszka Białego. Znamienne jest, że kronikarz, informując o obszarze działań militarnych wojsk polskich, wspominał, że wojowały „po Bugu”, co sugeruje, wbrew pojawiającym się w literaturze przedmiotu tezom, że to właśnie ta rzeka stała się główną linią obrony wojsk Daniela Romanowicza ${ }^{66}$. Książę ruski, mimo spodziewanej akcji odwetowej, nie próbował zorganizować obrony opierającej się na grodach ziem nadbużańskich. Zresztą brak o nich wiadomości źródłowych do początku XIII w. skłania do wniosku, że nie miały one poważniejszego znaczenia strategicznego na rubieży polsko-ruskiej. Przegrana księcia krakowskiego w czasie potyczki na tzw. suchej drodze zmusiła wojska polskie do odwrotu za Wieprz. Wspomniana rzeka w literaturze przedmiotu jest często wymieniana jako polsko-ruska rubież obronna, funkcjonująca co najmniej od początku XIII w. Tymczasem jeszcze w latach dwudziestych XIII w. taką właśnie rolę nadal odgrywała rzeka Bug. Przeświadczenie takie daje kolejny fragment Kroniki halicko-wołyńskiej opisujący wydarzenia z 1226 r. Wówczas to książę Leszek Biały zamierzał posiłkować króla węgierskiego Andrzeja II w walkach o Halicz. Jak zaznacza autor kroniki, to właśnie nad Bugiem obaj Romanowicze: Daniel i Wasylko, zorganizowali obronę, wzbraniając władcy krakowskiemu przejścia ${ }^{67}$.

Trwałe związanie terenów nadbużańskich z domeną włodzimierską nastąpiło dopiero w wyniku akcji osadniczej, jaką podjął w latach czterdziestych XIII w. książę Daniel Romanowicz. Decyzja władcy o budowie nowej rezydencji książęcej w Chełmie spowodowała, że dawne peryferie awansowały do rangi jednego z najważniej-

\footnotetext{
66 KHW, s. 60.

67 Tamże, s. 116.
} 
szych centrów księstwa halicko-włodzimierskiego. Wysiłki Daniela Romanowicza okazały się niezwykle trwałe.

Ponad 60 lat później inaczej już postrzegano obszar pogranicza. Autor Kroniki halicko-włodzimierskiej, opisując wydarzenia, jakie rozegrały się po śmierci księcia krakowskiego Bolesława Wstydliwego w 1279 r., wspominał, że książę ruski Lew Daniłowicz zamierzał również podjąć zabiegi w celu opanowania tronu krakowskiego. Brak szans na powodzenie całej akcji spowodował, że książę ruski zamieszanie związane z obsadą tronu krakowskiego postanowił wyzyskać w inny sposób: opanować jeden z grodów polskich na „okrainie”. Przyjmuje się, że grodem, o który zabiegał Daniłowicz, był Lublin ${ }^{68}$. Dla moich rozważań istotne jest, że w latach osiemdziesiątych XIII w. autor Kroniki halicko-włodzimierskiej ziemie okrainne utożsamiał już z okolicami Lublina.

Powyższe obserwacje pozwalają sformułować tezę, że w pamięci historiograficznej rzeka Bug i tereny nadbużańskie były traktowane jako rubież oddzielająca ziemie, które charakteryzowały się różnym stopniem podporządkowania władzy. U progu kształtowania się monarchii Rurykowiczów i Piastów rywalizacja obu dynastii toczyła się przede wszystkim o kontrolę nad ważnymi szlakami komunikacyjnymi, wśród których wspomniana rzeka odgrywała kluczową rolę. Bug nie tylko stanowił najważniejszą arterię łączącą społeczności zamieszkujące jej brzegi w czasach pokoju, lecz także miał istotne znaczenie militarne dla sąsiednich państw w okresie konfliktów. Tereny nadbużańskie, przez które prowadziły nieliczne drogi o przebiegu równoleżnikowym, przez długi czas znajdowały się jedynie pod nominalnym zwierzchnictwem rywalizujących władztw. Jakkolwiek od $1031 \mathrm{r}$. były traktowane jako podległe zwierzchnictwu Rurykowiczów i zaliczono je do wołości włodzimierskiej, to do pierwszej ćwierci XIII w. w środowisku związanym z dworem włodzimierskim dostrzegano ich specyficzny charakter. Właściwa dzielnica włodzimierska rozciągała się do Bugu, a peryferie nadbużańskie - tzw. ziemie okrainne były już obszarem odrębnym. Rzecz charakterystyczna, że dla Galla Anonima rzeka Bug również stanowiła confinium władztwa jego chlebodawców.

Ściślejsze podporządkowanie pod względem administracyjnym wspomnianego obszaru władzy Rurykowiczów nastąpiło w latach czterdziestych XIII w. Fluktuacja ta nie wynikała tylko z przesunięć granicy politycznej. Istotne znaczenie miały działania panujących, którzy inicjując akcję osadniczą, rozbudowując lokalne ośrodki grodowe, powodowali zawężanie terytorium, które utożsamiano z kresami. 
Nadesłany: 10 XI 2019

Nadesłany po poprawkach recenzyjnych: 30 XI 2020

Zaakceptowany: 15 I 2021

Dr hab. Mariusz Bartnicki

Instytut Historii, Uniwersytet Marii Curie-Skłodowskiej w Lublinie

pl. Marii Curie-Skłodowskiej 4a

20-031 Lublin

e-mail: mbartnicky@wp.pl

\section{Resume}

The article deals with the issue of the Polish-Ruthenian part of the Bug river in the Middle Ages and is an attempt to explain how the area was perceived by chroniclers from the two neighboring countries. An analysis of the sources results in a conclusion that each of the countries had different concepts regarding the geographic perception of the borders. Viewing the history of the Polish-Ruthenian borderland from the perspective of "geographic memory", based on different concepts of perceiving space, triggers off a reflection on the borderland between the two countries in the early Middle Ages. The article shows that the Bug river, at least until the 1230 s, played a dual role: it was both the most important transport route and, at the time of military conflicts between the Piasts and the Rurykids, it was transformed into a natural defensive zone.

Ttumaczenie: Ewa Dratwa 